\title{
THE EFFECT OF STORAGE ON THE COLIFORM AND BACTERIUM COLI COUNTS OF WATER SAMPLES
}

\author{
STORAGE FOR SIX HOURS AT ROOM AND REFRIGERATOR \\ TEMPERATURES
}

\section{By THE PUBLIC HEALTH LABORATORY SERVICE WATER SUB-COMMITTEE*}

It has already been shown by means of a 70-tube method (Report, 1952) that there is a change amounting to at least a doubling or halving of the coliform and faecal coli counts in a considerable proportion of water samples stored overnight. This finding was in general agreement with the results of most previous workers (Whipple, 1901; Caldwell \& Parr, 1933; Taylor \& Collins, 1949; and Jones, Franklin \& Thomas, 1950), but not with those of Hoather (1952).

In the present investigation the effect of storage for $6 \mathrm{hr}$. on the presumptive coliform and faecal coli counts has been compared with the effect of storage for $24 \mathrm{hr}$. A $6 \mathrm{hr}$. period of storage was chosen because it is recommended in the Bacteriological Examination of Water Supplies (Report, 1939) that 'All samples should therefore be despatched immediately after collection by the quickest route to the laboratories, the time occupied in transit being preferably less than $6 \mathrm{hr}$.'

Samples were at first stored at room temperature only, because it was felt that if waters showed no appreciable variation under these conditions, storage for $6 \mathrm{hr}$. might be acceptable. It soon became apparent, however, that $6 \mathrm{hr}$. storage at room temperature was not always satisfactory, and subsequent samples were stored in the refrigerator to simulate the transport of samples under ice-cold conditions. At the same time, in an attempt to identify more precisely the various influences which affect the response of waters to storage, each laboratory contributed samples towards a balanced experiment, in which laboratories, the sources of samples and the degree of initial pollution of the water should all be equally represented. Since these factors were unequally represented in the previous investigation (Report, 1952) it had not readily been possible to assess their effects separately. This experiment is discussed after the presentation of the main results.

\section{METHODS}

The methods of collecting and examining the samples of water were those described in the previous report (Report, 1952). Samples were collected from rivers, reservoirs, lakes, springs and wells in sterile Winchester bottles and transported to the

* The P.H.L.S. Water Sub-Committee is composed of the following members of the P.H.L.S. Staff: R. D. Gray, M.D., D.P.H. (Chairman); W. H. H. Jebb, M.A., M.D.; J. H. McCoy, M.B., B.Ch., D.P.H. ; J. Morrison Ritchie, M.A., M.B., Ch.B., D.P.H.; A. J. Kingsley Smith, B.M., B.Ch.; and Joan M. Watkinson, B.Sc.; together with E. Windle Taylor, M.A., M.D., D.P.H., Deputy Director of Water Examination, Metropolitan Water Board, London; and Ian Sutherland, M.A., D.Phil., of the M.R.C. Statistical Research Unit. 
laboratory without delay. As these samples were all drawn from unchlorinated sources thiosulphate was not used in the bottles.

More than 300 samples were collected from sampling points scattered over the following counties of England and Wales: Bedfordshire, Berkshire, Caernarvonshire, Cambridgeshire, Cheshire, Denbighshire, Essex, Hertfordshire, Kent, Lancashire, Monmouthshire, Northamptonshire, Oxfordshire, Surrey and West Suffolk. The samples were examined at seven laboratories-Birkenhead, Cambridge, Conway, London, Manchester, Newport (Mon.) and Oxford. For statistical reasons, described below, a number of the results were subsequently excluded from the analysis.

\section{Storage}

On arrival at the laboratory, within $1 \mathrm{hr}$. of sampling, the Winchester was inverted several times and a portion of the sample, approximately one-tenth, discarded. From the Winchester, after re-stoppering and vigorous shaking, three similar sterile bottles of $24 \mathrm{oz}$. capacity labelled A, B and C, were filled completely. Bottle A was examined immediately, Bottle B was stored in the dark at room temperature or in the refrigerator until $6 \mathrm{hr}$. had elapsed from the time of sampling, and bottle $\mathrm{C}$ was stored at the same temperature as bottle $\mathrm{B}$ until $24 \mathrm{hr}$. had elapsed from the time of sampling.

\section{Storage temperatures}

Room temperature. This varied according to the time of year, but usually lay between 16 and $23^{\circ} \mathrm{C}$.

Refrigerator temperature. This was consistent throughout the period between the limits of 2 and $5^{\circ} \mathrm{C}$.

\section{Technique of examination}

Ten tubes were inoculated with each of seven twofold diminishing volumes of the water sample. In accordance with the technical procedure described in Report no. 71 (1939), volumes of $32,16,8$ and $4 \mathrm{ml}$. of the sample were pipetted into tubes containing the same volumes of double-strength MacConkey broth while volumes of $2 \mathrm{ml}$. or less were added to tubes containing $5 \mathrm{ml}$. single-strength MacConkey broth. Sample volumes of less than $1 \mathrm{ml}$. were obtained by dilution of the water samples with sterile quarter-strength Ringer solution.

Inoculated tubes were incubated at $37^{\circ} \mathrm{C}$. and were examined after $24 \mathrm{hr}$. Those showing acid and gas production were subcultured and incubated at $44^{\circ} \mathrm{C}$. to test for the presence of faecal coli. Tubes not producing acid and gas at $37^{\circ} \mathrm{C}$. in $24 \mathrm{hr}$. were incubated for a further period of $24 \mathrm{hr}$. and if at the end of that period acid and gas were produced, these tubes were then subcultured and incubated at $44^{\circ} \mathrm{C}$.

\section{Methods of statistical analysis}

The total number of tubes with a positive reaction, out of the seventy inoculated, was recorded for each examination of a sample. From this number the density of organisms could be estimated quite simply by reference to the table in the Appendix. For a number of reasons, statistical and practical, it is more convenient, in studying the effect of storage, to work with the number of positive tubes and not the 
estimated density of organisms. An increase of nine in the total of positive tubes corresponds approximately to a doubling of the density of organisms, and an equal decrease to a halving of the number. A change of nine or more in the total of positive tubes might occur by chance even if there had really been no alteration in the density of organisms, but such a change would be expected to happen only about once in seventeen samples $(5 \cdot 8 \%)$, increases and decreases occurring equally frequently, i.e. each about once in thirty-four samples $(2.9 \%){ }^{*}$ As a working criterion, a difference of nine or more positive tubes between a sample tested as soon after collection as possible, and the same sample tested after storage, was taken to indicate a real change in the density of coliform organisms. Since a very low or very high total of positive tubes does not give as reliable an indication of the density of organisms, or of changes in density, as a less extreme total, no sample was included in the analysis for which the initial total of positive tubes was less than 5 or more than 64. Apart from these exclusions the results presented below incorporate all the samples tested in both present and previous investigations.

In the analysis of the main results the effects of storage under different conditions were compared by means of $x^{2}$ tests. For the balanced experiment more refined methods were called for, and these are described in a later section, and also in more detail in Appendix II of the previous paper (Report, 1952).

\section{RESULTS}

The distribution of the samples examined according to their initial coliform and faecal coli counts is set out for each laboratory in Table 1, and it will be observed that the samples are spread over a wide range.

Table 1. The initial coliform and faecal coli counts of all samples examined

\begin{tabular}{|c|c|c|c|c|c|c|}
\hline \multirow[b]{2}{*}{ Count } & \multirow[b]{2}{*}{ Laboratory } & \multicolumn{4}{|c|}{$\begin{array}{c}\text { Most probable number of organisms per } 100 \mathrm{ml} \text {. } \\
\text { before storage } \\
\text { No. of samples with }\end{array}$} & \multirow[b]{2}{*}{ Total sa mples } \\
\hline & & Under 20 & $20-49$ & $50-99$ & 100 or more & \\
\hline \multirow[t]{8}{*}{ Coliform } & Birkenhead & 11 & 15 & 6 & 18 & 50 \\
\hline & Cambridge & 13 & 5 & 2 & 5 & 25 \\
\hline & Conway & 17 & 20 & 3 & 23 & 63 \\
\hline & London & 11 & 11 & 12 & 12 & 46 \\
\hline & Manchester & 25 & 13 & 10 & 9 & 57 \\
\hline & Newport & 12 & 6 & 12 & 27 & 57 \\
\hline & Oxford & 21 & 19 & 9 & 17 & 66 \\
\hline & Total & 110 & 89 & 54 & 111 & 364 \\
\hline \multirow[t]{8}{*}{ Faecal coli } & Birkenhead & 19 & 4 & 2 & 15 & 40 \\
\hline & Cambridge & 13 & 1 & 2 & 3 & 19 \\
\hline & Conway & 19 & 5 & 7 & 6 & 37 \\
\hline & London & 18 & 10 & 10 & 9 & 47 \\
\hline & Manchester & 22 & 7 & 4 & 5 & 38 \\
\hline & Newport & 18 & 9 & 5 & 7 & 39 \\
\hline & Oxford & 29 & 10 & 5 & 11 & 55 \\
\hline & Total & 138 & 46 & 35 & 56 & 275 \\
\hline
\end{tabular}

* The percentages of $5 \cdot 0$ and 2.5 which were used in the earlier paper, were approximations to these figures. 


\section{Presumptive coliform content}

The figures in Table 2 present the findings in terms of a difference of nine or more positive tubes between the sample examined within $1 \mathrm{hr}$. of collection and after 6 and $24 \mathrm{hr}$. storage at room temperature and in the refrigerator.

Table 2. Effect of storage upon the presumptive coliform content of water samples

(Changes of nine or more positive tubes.)

\begin{tabular}{|c|c|c|c|c|c|c|c|c|c|}
\hline \multirow{2}{*}{$\begin{array}{c}\text { Period of } \\
\text { storage } \\
\text { (hr.) }\end{array}$} & \multirow[b]{2}{*}{$\begin{array}{c}\text { Temperature } \\
\text { of storage }\end{array}$} & \multirow[b]{2}{*}{$\begin{array}{c}\text { No. of } \\
\text { samples }\end{array}$} & \multicolumn{3}{|c|}{ No. showing } & \multicolumn{3}{|c|}{ Percentage showing } & \multirow[b]{2}{*}{$\begin{array}{c}\text { Increase } \\
\text { or decrease }\end{array}$} \\
\hline & & & Increase & $\begin{array}{c}\text { No } \\
\text { change }\end{array}$ & Decrease & Increase & $\begin{array}{c}\text { No } \\
\text { change }\end{array}$ & Decrease & \\
\hline 6 & $\begin{array}{l}\text { Refrigerator } \\
\text { Room }\end{array}$ & $\begin{array}{r}160 \\
93\end{array}$ & $\begin{array}{r}14 \\
8\end{array}$ & $\begin{array}{r}120 \\
70\end{array}$ & $\begin{array}{l}26 \\
15\end{array}$ & $\begin{array}{l}8 \cdot 8 \\
8 \cdot 6\end{array}$ & $\begin{array}{l}75 \cdot 0 \\
75 \cdot 3\end{array}$ & $\begin{array}{l}16 \cdot 2 \\
16 \cdot 1\end{array}$ & $\begin{array}{l}25 \cdot 0 \\
24 \cdot 7\end{array}$ \\
\hline 24 & $\begin{array}{l}\text { Refrigerator } \\
\text { Room }\end{array}$ & $\begin{array}{l}292 \\
227\end{array}$ & $\begin{array}{l}19 \\
33\end{array}$ & $\begin{array}{l}193 \\
140\end{array}$ & $\begin{array}{l}80 \\
54\end{array}$ & $\begin{array}{r}6.5 \\
14.5\end{array}$ & $\begin{array}{l}66 \cdot 1 \\
61 \cdot 7\end{array}$ & $\begin{array}{l}27 \cdot 4 \\
23 \cdot 8\end{array}$ & $\begin{array}{l}33 \cdot 9 \\
38 \cdot 3\end{array}$ \\
\hline & & & \multicolumn{3}{|c|}{ Theoretical percentage } & $\mathbf{2 \cdot 9}$ & $\mathbf{9 4 \cdot 2}$ & $2 \cdot 9$ & $5 \cdot 8$ \\
\hline
\end{tabular}

On storage for $6 \mathrm{hr}$. at each temperature there were almost twice as many significant decreases as increases and the figures for the two temperatures were very similar. At each temperature approximately one sample in four showed a significant variation after $6 \mathrm{hr}$. storage.

After $24 \mathrm{hr}$. storage there were rather fewer significant increases in the refrigerator than occurred at room temperature, but the percentages of decreases at the two temperatures were very similar. Decreases occurred more frequently than increases at both temperatures, but it is apparent that real changes in the coliform content occurred in about a third of the samples examined after storage at each temperature.

It would appear that so far as the coliform count is concerned there is little to choose between the two temperatures up to $6 \mathrm{hr}$. storage, but the superiority of refrigerator temperature is more evident after $24 \mathrm{hr}$. storage. Storage for $6 \mathrm{hr}$. only, even at room temperature, is to be preferred to $24 \mathrm{hr}$. in the refrigerator, for only one sample in four showed a significant variation after $6 \mathrm{hr}$. at room temperature, whereas one sample in three showed a significant change after $24 \mathrm{hr}$. in the refrigerator.

\section{Faecal coli content}

The figures in Table 3 present the findings in terms of a difference of nine or more positive tubes between the sample examined as soon after collection as possible and after 6 and $24 \mathrm{hr}$. storage at room temperature or in the refrigerator.

On storage for $6 \mathrm{hr}$. at room temperature there were twice as many significant decreases in faecal coli content as increases, and on storage in the refrigerator there were almost six times as many significant decreases as increases $(8.9 \%$ compared with $1.5 \%$ ). The percentage of increases on storage in the refrigerator was less than would be expected to occur by chance. Although the percentage of significant changes in faecal coli content after storage for $6 \mathrm{hr}$. in the refrigerator $(10.4 \%)$ was only about half the percentage showing a significant change after storage at room 
temperature $(18.7 \%)$, the faecal coli content of approximately one sample in ten varied significantly even when stored for $6 \mathrm{hr}$. in the refrigerator.

After $24 \mathrm{hr}$. in the refrigerator the increases $(3 \cdot 5 \%)$ in faecal coli content were little more than would be expected to occur by chance, but the decreases $(21.5 \%)$ were very much greater. There were fewer increases and decreases after storage in the refrigerator than after storage at room temperature, but the percentage of decreases in the faecal coli content after storage for $24 \mathrm{hr}$. at each temperature was considerable.

Table 3. Effect of storage upon the faecal coli content of water samples

(Changes of nine or more positive tubes.)

\begin{tabular}{|c|c|c|c|c|c|c|c|c|c|}
\hline \multirow{2}{*}{$\begin{array}{l}\text { eriod of } \\
\text { torage } \\
\text { (hr.) }\end{array}$} & \multirow[b]{2}{*}{$\begin{array}{c}\text { Temperature } \\
\text { of storage }\end{array}$} & \multirow[b]{2}{*}{$\begin{array}{c}\text { No. of } \\
\text { samples }\end{array}$} & \multicolumn{3}{|c|}{ No. showing } & \multicolumn{3}{|c|}{ Percentage showing } & \multirow[b]{2}{*}{$\begin{array}{l}\text { Increase } \\
\text { or decrease }\end{array}$} \\
\hline & & & Increase & $\begin{array}{c}\text { No } \\
\text { change }\end{array}$ & Decrease & Increase & $\begin{array}{c}\text { No } \\
\text { change }\end{array}$ & Decrease & \\
\hline 6 & $\begin{array}{l}\text { Refrigerator } \\
\text { Room }\end{array}$ & $\begin{array}{r}135 \\
64\end{array}$ & $\begin{array}{l}2 \\
4\end{array}$ & $\begin{array}{r}121 \\
52\end{array}$ & $\begin{array}{r}12 \\
8\end{array}$ & $\begin{array}{l}1 \cdot 5 \\
6 \cdot 2\end{array}$ & $\begin{array}{l}89 \cdot 6 \\
81 \cdot 3\end{array}$ & $\begin{array}{r}8 \cdot 9 \\
12 \cdot 5\end{array}$ & $\begin{array}{l}10 \cdot 4 \\
18 \cdot 7\end{array}$ \\
\hline \multirow[t]{2}{*}{24} & $\begin{array}{l}\text { Refrigerator } \\
\text { Room }\end{array}$ & $\begin{array}{l}228 \\
159\end{array}$ & $\begin{array}{l}8 \\
9\end{array}$ & $\begin{array}{l}171 \\
104\end{array}$ & $\begin{array}{l}49 \\
46\end{array}$ & $\begin{array}{l}3 \cdot 5 \\
5 \cdot 7\end{array}$ & $\begin{array}{l}75 \cdot 0 \\
65 \cdot 4\end{array}$ & $\begin{array}{l}21 \cdot 5 \\
28 \cdot 9\end{array}$ & $\begin{array}{l}25 \cdot 0 \\
34 \cdot 6\end{array}$ \\
\hline & \multicolumn{5}{|c|}{ Theoretical percentage } & $2 \cdot 9$ & $94 \cdot 2$ & $2 \cdot 9$ & $5 \cdot 8$ \\
\hline
\end{tabular}

At each temperature there was less variation in faecal coli content after $6 \mathrm{hr}$. storage than after $24 \mathrm{hr}$.

After storage in the refrigerator, one sample in ten showed a significant change in faecal coli content after $6 \mathrm{hr}$., whereas one sample in four showed a significant change after $24 \mathrm{hr}$.

So far as the faecal coli content is concerned storage in the refrigerator for $6 \mathrm{hr}$. is to be preferred to storage at room temperature, and either temperature for $6 \mathrm{hr}$. is to be preferred to storage for $24 \mathrm{hr}$. in the refrigerator.

Extent of changes in coliform and faecal coli content after 6 and $24 \mathrm{hr}$.

Tables 2 and 3 show that real changes take place in the presumptive coliform and faecal coli content of water samples after storage. It is of considerable practical interest to know the probable extent of these changes, and this information is presented in Table 4.

Table 4. The extent of variations in the most probable number of coliform or faecal coli organisms after storage

\begin{tabular}{|c|c|c|c|c|c|c|c|c|c|c|c|c|c|c|c|}
\hline \multirow{2}{*}{\multicolumn{2}{|c|}{$\begin{array}{cc}\begin{array}{c}\text { Period } \\
\text { of }\end{array} \\
\text { pe of } \\
\text { test } & \begin{array}{c}\text { (hr.) } \\
\text { thage }\end{array}\end{array}$}} & \multirow{3}{*}{$\begin{array}{l}\text { Temperature } \\
\text { of storage } \\
\text { Refrigerator }\end{array}$} & \multicolumn{6}{|c|}{ Increases } & \multirow{3}{*}{$\begin{array}{l}\text { No } \\
\text { significant } \\
\text { change } \\
120\end{array}$} & \multicolumn{6}{|c|}{ Decreases } \\
\hline & & & $\begin{array}{l}7 \text {-fold } \\
\text { or more }\end{array}$ & $\begin{array}{l}6 \text { - to } \\
\text { 7-fold }\end{array}$ & $\begin{array}{l}\text { 5- to } \\
6 \text {-fold }\end{array}$ & $\begin{array}{l}\text { 4- to } \\
5 \text {-fold }\end{array}$ & $\begin{array}{l}3 \text { - to } \\
4 \text {-fold }\end{array}$ & $\begin{array}{l}\text { 2-to } \\
\text { 3-fold }\end{array}$ & & $\begin{array}{l}2-\text { to } \\
\text { 3-fold }\end{array}$ & $\begin{array}{l}\text { 3-to } \\
\text { 4-fold }\end{array}$ & $\begin{array}{l}\text { 4- to } \\
\text { 5-fold }\end{array}$ & $\begin{array}{l}\text { 5- to } \\
6 \text {-fold }\end{array}$ & $\begin{array}{l}\text { 6- to } \\
7 \text {-fold }\end{array}$ & $\begin{array}{l}\text { 7-fold } \\
\text { or more }\end{array}$ \\
\hline & & & 1 & 0 & 0 & 0 & 4 & 9 & & 18 & 5 & 3 & 0 & 0 & 0 \\
\hline & & Room & 1 & 0 & 0 & 1 & 1 & 5 & 70 & 9 & 2 & 0 & 1 & 1 & 2 \\
\hline & 24 & $\begin{array}{l}\text { Refrigerator } \\
\text { Room }\end{array}$ & $\frac{1}{2}$ & $\begin{array}{l}0 \\
0\end{array}$ & $\frac{1}{5}$ & $\underset{2}{0}$ & $\begin{array}{l}5 \\
8\end{array}$ & $\begin{array}{l}12 \\
16\end{array}$ & $\begin{array}{l}193 \\
140\end{array}$ & $\begin{array}{l}30 \\
20\end{array}$ & $\begin{array}{r}16 \\
9\end{array}$ & $\begin{array}{l}8 \\
\mathbf{2}\end{array}$ & $\begin{array}{l}5 \\
3\end{array}$ & $\begin{array}{l}1 \\
4\end{array}$ & $\begin{array}{l}20 \\
16\end{array}$ \\
\hline al coli & 6 & $\begin{array}{l}\text { Refrigerator } \\
\text { Room }\end{array}$ & $\begin{array}{l}0 \\
0\end{array}$ & $\begin{array}{l}0 \\
0\end{array}$ & $\begin{array}{l}0 \\
0\end{array}$ & $\begin{array}{l}0 \\
0\end{array}$ & $\begin{array}{l}0 \\
0\end{array}$ & $\begin{array}{l}2 \\
4\end{array}$ & $\begin{array}{r}121 \\
52\end{array}$ & $\begin{array}{l}7 \\
4\end{array}$ & $\begin{array}{l}0 \\
1\end{array}$ & $\begin{array}{l}1 \\
0\end{array}$ & $\begin{array}{l}1 \\
1\end{array}$ & $\begin{array}{l}1 \\
1\end{array}$ & $\begin{array}{l}2 \\
1\end{array}$ \\
\hline & 24 & $\begin{array}{l}\text { Refrigerator } \\
\text { Room }\end{array}$ & $\begin{array}{l}1 \\
1\end{array}$ & $\begin{array}{l}0 \\
0\end{array}$ & $\begin{array}{l}0 \\
0\end{array}$ & $\begin{array}{l}0 \\
1\end{array}$ & $\begin{array}{l}2 \\
3\end{array}$ & $\begin{array}{l}5 \\
4\end{array}$ & $\begin{array}{l}171 \\
104\end{array}$ & $\begin{array}{l}21 \\
17\end{array}$ & $\begin{array}{r}11 \\
6\end{array}$ & $\begin{array}{l}5 \\
1\end{array}$ & $\begin{array}{l}1 \\
4\end{array}$ & $\begin{array}{l}2 \\
1\end{array}$ & $\begin{array}{r}9 \\
17\end{array}$ \\
\hline
\end{tabular}


A change of sevenfold or more is considerable and well beyond the limits of chance: in the whole series such a change occurred on seventy-four occasions. Most of these large changes occurred after $24 \mathrm{hr}$. storage; they amounted to $67(4.9 \%$ of the samples examined), of which 62 were decreases, almost equally divided between room (33) and refrigerator (29) temperatures. There were very few large variations after $6 \mathrm{hr}$. storage at either temperature; large increases were recorded on only two occasions, and decreases on five, i.e. altogether on $0.5 \%$ of the samples examined.

Large increases and decreases were fairly evenly divided between the presumptive coliform content and the faecal coli results. Further analysis showed that large changes were as likely to occur in heavily as in lightly polluted waters.

Thus the possibility of so large a change in the coliform and faecal coli content of a sample set up within $6 \mathrm{hr}$. of sampling is remote ( 1 in 200$)$. There is a much greater probability ( 1 in 20 ) of a large change, particularly in the direction of a decrease, in either the coliform or faecal coli content of a sample, if it is stored for $24 \mathrm{hr}$. at either room or refrigerator temperature before the test is set up.

\section{Inferences from main part of 70-tube experiment}

(1) The presumptive coliform content shows a greater tendency to change than the faecal coli content under the same conditions.

(2) Both the presumptive coliform content and the faecal coli content show less tendency to change when the sample is stored in the refrigerator than when it is stored at room temperature. This applies to both periods of storage, though the difference in the percentages showing variation in the presumptive coliform content at the two temperatures is negligible after $6 \mathrm{hr}$. and small after $24 \mathrm{hr}$.

(3) Storage for $6 \mathrm{hr}$. is greatly to be preferred to storage for $24 \mathrm{hr}$. at either temperature. This is particularly true of the faecal coli counts. Storage for $6 \mathrm{hr}$. at room temperature is to be preferred to storage for $24 \mathrm{hr}$. in the refrigerator.

(4) When stored under the most favourable conditions (i.e. $6 \mathrm{hr}$. in the refrigerator) one sample in four shows a significant change in the presumptive coliform content and one in ten in the faecal coli content.

(5) There are more significant decreases than increases in both presumptive coliform content and faecal coli content after storage at either temperature for either time. In general this tendency is more evident in the faecal coli content than in the presumptive coliform content, and on storage in the refrigerator than at room temperature.

(6) There are many more very large changes in both presumptive coliform and faecal coli content after $24 \mathrm{hr}$. storage at either temperature than there are after $6 \mathrm{hr}$. storage at either temperature.

\section{Balanced experiment}

In the previous paper (Report, 1952) it was shown that the response of water samples to storage appeared to depend in some way upon the particular laboratory, the source of the samples, the degree of initial pollution and the season of sampling. Since these influences were unequally represented among the samples of the earlier 
investigation it was not readily possible to disentangle their respective effects. It was therefore decided that in the course of the experiments which are described in this paper, each laboratory should contribute samples towards a balanced experiment in which the laboratories, the sources and the degrees of initial pollution of the water should all be equally represented.

Each sample was tested by the 70-tube method within $1 \mathrm{hr}$. of sampling and again after $6 \mathrm{hr}$. and after $24 \mathrm{hr}$. storage at refrigerator temperature. Each of six laboratories contributed sixteen samples on which presumptive coliform counts, and sixteen on which faecal coli counts, had been made. The samples from each laboratory had to fit into the following scheme:

$\begin{array}{lccccc}\text { Source } & \overbrace{\begin{array}{c}\text { Under } 50 \\ \text { per } 100 \mathrm{ml} \text {. }\end{array}}^{\text {Initial coliform count } 100 \mathrm{ml}} \begin{array}{c}\text { and over } \\ \text { Underground }\end{array} & 4 & 4 & \overbrace{\begin{array}{c}\text { Under } 20 \\ \text { per } 100 \mathrm{ml} \text {. }\end{array}}^{\text {Initial faecal coli count } 100 \mathrm{ml} \text { and over }} \\ \text { Surface } & 4 & 4 & 4 & 4 \\ \text { and } & 4 & 4 & 4 & 4\end{array}$

Often the same water contributed to the schemes for the coliform counts and for the faecal coli counts.

The techniques of statistical analysis were the same as before, but the detailed analyses are omitted to save space. The principal findings are presented in Tables 5 and 6 .

\section{Average changes of content}

The general tendency was for the content of organisms in the sample to decrease on storage, although there were many exceptions. This tendency was more pronounced after storage for $24 \mathrm{hr}$. than after $6 \mathrm{hr}$. and varied significantly from

Table 5. Effect of storage at refrigerator temperature on the presumptive and faecal coli content of water samples

(Average increases in totals of positive tubes.)

\begin{tabular}{|c|c|c|c|c|c|}
\hline \multirow[b]{2}{*}{ Laboratory } & \multirow{2}{*}{$\begin{array}{l}\text { No. of } \\
\text { samples }\end{array}$} & \multicolumn{2}{|c|}{ Presumptive coli } & \multicolumn{2}{|c|}{ Faecal coli } \\
\hline & & $6 \mathrm{hr}$. & $24 \mathrm{hr}$. & $6 \mathrm{hr}$. & $24 \mathrm{hr}$. \\
\hline Birkenhead & 16 & $-8 \cdot 3$ & $-19 \cdot 1$ & $-4 \cdot 4$ & $-11 \cdot 8$ \\
\hline Conway & 16 & $-1 \cdot 7$ & $-4 \cdot 8$ & -0.8 & $-5 \cdot 0$ \\
\hline London & 16 & $-0 \cdot 1$ & $-5 \cdot 8$ & -0.5 & $-6 \cdot 2$ \\
\hline Manchester & 16 & $-3 \cdot 4$ & $-8 \cdot 1$ & $-4 \cdot 2$ & $-4 \cdot 8$ \\
\hline Newport & 16 & $+4 \cdot 8$ & $-0 \cdot 4$ & $0 \cdot 0$ & $-1 \cdot 4$ \\
\hline Oxford & 16 & $-3 \cdot 4$ & $-4 \cdot 7$ & -1.9 & $-1 \cdot 1$ \\
\hline Total & 96 & $-2 \cdot 0$ & $-7 \cdot 1$ & $-2 \cdot 0$ & $-5 \cdot 0$ \\
\hline
\end{tabular}

(A negative sign indicates a decrease in the total of positive tubes.)

laboratory to laboratory. The average changes in the number of tubes with a positive reaction, out of seventy inoculated, are shown in Table 5 for each laboratory separately, and for the whole experiment. The most pronounced decreases were at Birkenhead. At Newport the coliform counts tended to increase and the faecal coli 
counts to remain level after $6 \mathrm{hr}$. storage, although after $24 \mathrm{hr}$. both counts tended to drop slightly below the initial level. In London there was little change after $6 \mathrm{hr}$. but a tendency to decrease after $24 \mathrm{hr}$. storage for both coliform and faecal coli counts.

Although the average response varied from laboratory to laboratory, there were no important differences between the average response of surface and underground waters, nor between waters with different levels of pollution, with the exception that the faecal coli content of surface waters decreased more than that of the underground waters after storage for $24 \mathrm{hr}$. The respective average decreases in the totals of positive tubes were $3 \cdot 7$ and $6 \cdot 4$. This isolated finding suggests that although the nature of the source plays some part in the response to storage, the influences which are responsible are not primarily those with which this investigation is concerned. A simple division of the waters into surface and underground happens, on this one occasion, to have thrown the effect of these other influences into prominence, but this division, it seems, is not always relevant.

\section{Variability of response}

The examination of average changes is of interest principally for the evidence which it provides of lack of uniformity in response of waters; the slight general tendencies which are revealed are of small practical importance. The total frequency with which such increases and decreases occur is of considerably more practical interest to those concerned with the routine testing of water supplies than whether or not they occur equally frequently. Table 6 gives the numbers of waters which showed increases or decreases of at least nine positive tubes on storage.

Table 6. Effect of storage at refrigerator temperature on the presumptive and faecal coli content of water samples

(Number of samples showing an increase or decrease of nine or more positive tubes on storage.)

\begin{tabular}{|c|c|c|c|c|c|c|}
\hline \multirow[b]{2}{*}{ Source } & \multirow[b]{2}{*}{$\begin{array}{l}\text { No. of } \\
\text { samples }\end{array}$} & \multicolumn{2}{|c|}{ Presumptive coli } & \multirow[b]{2}{*}{ Source } & \multicolumn{2}{|c|}{ Faecal coli } \\
\hline & & $6 \mathrm{hr}$. & $24 \mathrm{hr}$. & & $6 \mathrm{hr}$. & $24 \mathrm{hr}$. \\
\hline Underground & 48 & 17 & 23 & Underground & 8 & 10 \\
\hline Surface & 48 & 8 & 24 & Surface & 4 & 17 \\
\hline $\begin{array}{c}\text { Initial count } \\
\text { Under } 50 \text { ner } 100 \mathrm{ml}\end{array}$ & 48 & 13 & 26 & $\begin{array}{c}\text { Initial count } \\
\end{array}$ & 5 & 9 \\
\hline $\begin{array}{l}50 \text { per } 100 \mathrm{ml} \text {. and } \\
\text { over }\end{array}$ & $\begin{array}{l}48 \\
48\end{array}$ & $\begin{array}{l}13 \\
12\end{array}$ & $\begin{array}{l}20 \\
21\end{array}$ & $\begin{array}{l}20 \text { per } 100 \mathrm{ml} \text {. and } \\
\text { over }\end{array}$ & 7 & 18 \\
\hline Total & 96 & 25 & 47 & & 12 & 27 \\
\hline Theoretical total & 96 & 5 & 5 & & 5 & 5 \\
\hline
\end{tabular}

The final row of the table indicates that if there had been no real changes in coliform content, only five samples in each category would have been expected to show increases or decreases of at least nine positive tubes. The actual numbers are considerably larger, showing that real changes in coliform and faecal coli content take place, even after storage for $6 \mathrm{hr}$. at refrigerator temperature. 
The first two rows of figures in Table 6 show differences associated with the source of the water sample. After $6 \mathrm{hr}$. storage more underground than surface waters show a significant change in content, but after $24 \mathrm{hr}$. the tendencyparticularly for faecal coli counts-is reversed. The interpretation of this is not clear; it is unlikely to be due to chance. The effect of the initial degree of pollution, as indicated by the third and fourth rows of figures, is unimportant except that the faecal coli count of heavily polluted waters shows more changes after $24 \mathrm{hr}$. than that for lightly polluted waters. The figures for separate laboratories are not tabulated, but there are no important differences between them in the scatter of the results, as distinct from the changes in average response described above.

\section{Inferences to be drawn from balanced experiment}

The findings of the balanced experiment are thus rather puzzling. The earlier analyses by laboratory, source and degree of initial pollution were also hard to interpret, and it was suggested (Report, 1952) that this might be because the effects of these influences were confused with one another for statistical reasons. The purpose of the balanced experiment was to disentangle any consistent effects of these influences. The disappointing fact that it has not done so is the fault not of the method but of the material to which it was applied. The laboratory, type of source, and degree of initial pollution, although on occasion of undoubted importance, do not affect the response of the waters to storage with sufficient consistency to be of much use for predicting how they may do so in future experiments. The value of the balanced experiment has therefore been to make it clear that these investigations have no more than indicated the difficulty of the problem; the influences which determine the response of water to storage must be more complex than those which have here been studied.

\section{DISCUSSION}

The scope of the investigations recorded here was determined by the finding in a previous investigation (Report, 1952), that in a substantial percentage of waters the coliform and faecal coli content were significantly altered by overnight storage, either at room temperature or in the refrigerator, and by the suggestion implied in the finding that the source and the initial degree of pollution of the sample might in some way be responsible for, if not the absolute changes, at least the tendency towards variation of waters on storage.

It was thought that the variations found in waters examined after storage for $24 \mathrm{hr}$. at room and refrigerator temperatures might be greatly diminished by a shorter interval between collection and examination of samples. Six hours after collection was chosen as the maximum time within which samples examined in a laboratory carrying out routine examinations of waters might reasonably be expected to be examined, and this time is in keeping with the Ministry of Health's (Report, 1939) recommendations.

Not only were the percentages of samples showing significant changes less after 6 than after $24 \mathrm{hr}$. storage at each temperature, but the percentages showing large 
variations and in particular large decreases were smaller after 6 than after $24 \mathrm{hr}$. storage (Table 4).

Under all conditions of storage significant decreases were much more frequent than significant increases in both the coliform and the faecal coli content, and in general large decreases occurred more frequently than large increases. In view of these changes, it is evident that a proportion of erroneous judgements will be made after storage of samples for $6 \mathrm{hr}$., and a larger proportion after storage for $24 \mathrm{hr}$. Some of these will consist in rejecting an acceptable water and others, more numerous as well as more serious, in passing a water as suitable that would have been rejected if it had been tested immediately after sampling. No estimate of the size of these proportions can be given, since the chance of an erroneous judgement will depend on the initial coliform or faecal coli content of the sample. The chance will naturally be greatest if the initial content is of the same order of magnitude as the permitted standard.

Ideally, water intended for drinking and dairy purposes should contain no coliform organisms, and serious error in the assessment of a water examined after storage would, if that standard was observed, occur only where there was a drop in the coliform content to zero after storage. In the previous report (Report, 1952) it was noted that a significant drop in the coliform count to zero occurred only once-after storage for $24 \mathrm{hr}$. at room temperature. On three occasions the faecal coli count showed a significant drop to zero but a significant drop to zero was never observed in either coliform or faecal coli count after storage for $6 \mathrm{hr}$.

The findings of the balanced experiment were rather disappointing. The laboratory at which the sample was examined, the nature of the source from which the sample was obtained, and the initial degree of pollution of the sample, did not exert any measurable influence on the tendency of the stored sample to vary. It is possible that the tendency of some waters to change may be associated with their geographical situation.

Table 5, which shows the average variation encountered at each of the laboratories during the balanced experiment, indicates that with the exception of an increase in coliform organisms in samples stored for $6 \mathrm{hr}$. at Newport, the general trend is towards a decrease on storage. The table does focus attention on the point that the general tendency of the content of organisms of a water on storage is to change, and that the range of variation may be wide. Other similar instances of wide variations in the coliform and faecal coli content of waters on storage have been found. Jones et al. (1950), in their study of farm water samples from South Wales, found variations in coliform and faecal coli content after $20 \mathrm{hr}$. storage considerably larger than those found here. The percentages of significant changes were actually very similar. However, these authors used the Report no. 71 (1939) method of examination, which is less precise than the 70-tube method; with the standard method a significant change in content corresponds approximately to a four- or fivefold increase or decrease in the density of organisms. They likewise found that decreases in content occurred more frequently than increases.

In contrast, Hoather (1952), also using the Report no. 71 (1939) method, examined 140 samples on the day of collection and on the following day, after 
storage at 5 and $20^{\circ} \mathrm{C}$. in bottles containing thiosulphate, and concluded that there were no changes in the real numbers of coliform organisms after overnight storage at either temperature. His initial examinations, however, were not set up until between 3 and $7 \mathrm{hr}$. after collection of the sample.

As a matter of practice, therefore, it would seem to be wise to examine samples of water as soon after collection as is practicable, and in no case should the interval between collection and examination exceed $6 \mathrm{hr}$. If possible the sample should be stored in ice until it is examined. Storage for more than $6 \mathrm{hr}$.- even in ice-is strenuously to be avoided. Even when samples are stored in ice for $6 \mathrm{hr}$. one in four of them will show a change amounting to a doubling or halving in their coliform content and one in ten a similar change in their faecal coli content.

\section{SUMMARY}

This investigation has been concerned with the changes that occur in the coliform and faecal coli content of water samples on storage at room and refrigerator temperatures for $6 \mathrm{hr}$. as compared with those occurring after $24 \mathrm{hr}$. storage.

The examination was conducted by a 70-tube method using twofold diminishing volumes.

The percentages of samples showing a significant change corresponding to at least a doubling or halving of the coliform content on storage were: $(a)$ at room temperature after $6 \mathrm{hr} .24 \cdot 7 \%$, and after $24 \mathrm{hr} .38 \cdot 3 \%$; $(b)$ at refrigerator temperature after $6 \mathrm{hr} .25 \cdot 0 \%$, and after $24 \mathrm{hr} .33 \cdot 9 \%$. The percentages of samples showing a significant change in the faecal coli content on storage were: $(a)$ at room temperature after $6 \mathrm{hr} .18 \cdot 7 \%$, and after $24 \mathrm{hr} .34 \cdot 6 \% ;(b)$ at refrigerator temperature after $6 \mathrm{hr} .10 \cdot 4 \%$, and after $24 \mathrm{hr} .25 \cdot 0 \%$. The changes were preponderantly decreases and most of the large changes occurred after $24 \mathrm{hr}$.

The investigation has shown that fewer changes occur after $6 \mathrm{hr}$. storage than after $24 \mathrm{hr}$. storage, and that storage for $6 \mathrm{hr}$. at refrigerator temperature is preferable to storage for $6 \mathrm{hr}$. at room temperature. Even so, some samples show significant changes after $6 \mathrm{hr}$. storage at refrigerator temperature; the coliform content is significantly altered in $25 \%$ of samples and the faecal coli content in $10 \%$ of samples.

Samples of water should, therefore, be examined as soon as possible after collection, certainly within $6 \mathrm{hr}$., and during the period of transport to the laboratory they should be kept cold, if possible by ice.

\section{REFERENCES}

Caldwell, E. L. \& Parr, L. W. (1933). Amer. J. publ. Hlth, 23, 467.

HOATHER, R. C. (1952). J. Instn Wat. Engrs, 6, 426.

Jones, G. E., Frankin, P. M. \& Thomas, S. B. (1950). Proc. Soc. appl. Bact. 13, 108.

REPORT (1939). Ministry of Health, The Bacteriological Examination of Water Supplies. Rep. publ. Hlth med. Subj., Lond., no. 71. London: H.M.S.O.

Report (1952). Public Health Laboratory Service Water Sub-Committee. J. Hyg., Camb., $50,107$.

TaYLor, C. B. \& Collins, B. G. (1949). J. gen. Microbiol. 3, 32.

WhIPPLE, G. C. (1901). Technol. Quart. 14, 21. 


\section{APPENDIX}

Expected numbers of organisms per $100 \mathrm{ml}$. of water in a test with ten tubes at each of seven volumes, diminishing twofold, the highest volume of water being respectively, 32, 16 or $8 \mathrm{ml}$.

Number of
tubes with
positive reaction

$$
5
$$$$
6
$$$$
7
$$$$
8
$$$$
9
$$$$
10
$$$$
11
$$$$
12
$$$$
13
$$$$
14
$$$$
15
$$$$
16
$$$$
17
$$$$
18
$$$$
19
$$$$
20
$$$$
21
$$$$
22
$$$$
23
$$$$
24
$$$$
25
$$$$
26
$$$$
27
$$$$
28
$$$$
29
$$$$
30
$$$$
31
$$$$
32
$$$$
33
$$$$
34
$$$$
35
$$$$
36
$$$$
37
$$$$
38
$$$$
39
$$$$
40
$$$$
41
$$$$
42
$$$$
43
$$$$
44
$$$$
45
$$$$
46
$$$$
47
$$$$
48
$$

49
Most probable number of organisms per $100 \mathrm{ml}$. Highest of seven volumes

\begin{tabular}{|c|c|c|}
\hline $32 \mathrm{ml}$. & $16 \mathrm{ml}$ & $8 \mathrm{ml}$. \\
\hline 1 & 2 & $\mathbf{3}$ \\
\hline 1 & 2 & 4 \\
\hline 1 & 3 & 5 \\
\hline 1 & 3 & 6 \\
\hline 2 & 3 & 7 \\
\hline 2 & 4 & 8 \\
\hline 2 & 4 & 9 \\
\hline 2 & 5 & 10 \\
\hline 3 & 5 & 11 \\
\hline $\mathbf{3}$ & 6 & 12 \\
\hline 3 & 6 & 13 \\
\hline 4 & 7 & 14 \\
\hline 4 & 8 & 15 \\
\hline 4 & 8 & 17 \\
\hline 5 & 9 & 18 \\
\hline 5 & 10 & 20 \\
\hline 5 & 11 & 21 \\
\hline 6 & 11 & 23 \\
\hline 6 & 12 & 25 \\
\hline 7 & 13 & 27 \\
\hline 7 & 14 & 29 \\
\hline 8 & 15 & 31 \\
\hline 8 & 17 & 33 \\
\hline 9 & 18 & 36 \\
\hline 10 & 19 & 38 \\
\hline 10 & 21 & 41 \\
\hline 11 & 22 & 44 \\
\hline 12 & 24 & 48 \\
\hline 13 & 26 & 51 \\
\hline 14 & 28 & 55 \\
\hline 15 & 30 & 59 \\
\hline 16 & 32 & 64 \\
\hline 17 & 34 & 69 \\
\hline 18 & 37 & 74 \\
\hline 20 & 40 & 79 \\
\hline 21 & 43 & 85 \\
\hline 23 & 46 & 92 \\
\hline 25 & 50 & 99 \\
\hline 27 & 53 & 107 \\
\hline 29 & 58 & 115 \\
\hline 31 & 62 & 125 \\
\hline 34 & 67 & 135 \\
\hline 36 & 73 & 146 \\
\hline 39 & 79 & 158 \\
\hline 43 & 86 & 171 \\
\hline
\end{tabular}


Appendix (cont.)

Number of Most probable number of organisms per $100 \mathrm{ml}$. tubes with positive reaction 50 51

52

Highest of seven volumes

$\begin{array}{rcc}32 \mathrm{ml} . & 16 \mathrm{ml} & 8 \mathrm{ml} \\ 46 & 93 & 185 \\ 50 & 100 & 201 \\ 55 & 109 & 218 \\ 59 & 119 & 238 \\ 65 & 129 & 259 \\ 71 & 142 & 283 \\ 77 & 155 & 310 \\ 85 & 170 & 340 \\ 93 & 187 & 373 \\ 103 & 206 & 411 \\ 114 & 228 & 455 \\ 126 & 252 & 505 \\ 141 & 282 & 564 \\ 158 & 317 & 634 \\ 179 & 359 & 718\end{array}$

(MS. received for publication 1. vI. 53) 